\title{
Nutritional and Keeping Quality Characteristics of Value Added Composite Flour Sev
}

\author{
Laxmi Pandey ${ }^{1}$, Veenu Sangwan ${ }^{2}$ and Kamla Malik ${ }^{3}$
}

${ }^{1}$ Department of Food Science and Nutrition, College of Home Science, MPUAT, Udaipur, Rajasthan-313001, India

${ }^{2}$ Department of Foods and Nutrition, I.C College of Home Science, CCS Haryana Agricultural University, Hisar, Haryana- 125004, India

${ }^{3}$ Department of Microbiology, College of Basic Sciences and Humanities, CCS Haryana Agricultural University, Hisar, Haryana- 125004, India

*Corresponding author

\section{A B S T R A C T}

\section{Keywords}

Keeping quality, Composite flour, Sevs,

Supplementation, Nutritive value

Article Info

Accepted:

26 December 2017

Available Online:

10 January 2018
The study was done to assess the nutritional and keeping quality characteristics of value added sev developed from newly released wheat varieties' (WH-1129 and HD-2967) flours supplemented with sorghum and soybean flours. The control sev had mean score of overall acceptability 6.16 whereas all other types of sevs made from composite flours had mean scores of overall acceptability ranging from 7.48 to 8.32 , which were significantly higher $(\mathrm{P} \leq 0.05)$ than that of control sev. The protein and fat content in control sev were 9.32 and 13.48 per cent, respectively which significantly $(\mathrm{P} \leq 0.05)$ increased in composite flour sev of WH-1129 wheat flour to 11.36 and 16.55 per cent, respectively and to 11.19 and 17.14 per cent, respectively in that of HD-2967 flour. The crude fibre and ash contents in control sev were 1.56 and 3.56 per cent, respectively which significantly $(\mathrm{P} \leq 0.05)$ increased in composite sevs of WH-1129 flour to 4.23 and 3.87 per cent, respectively and to 3.53 and 3.47 per cent, respectively in that of HD-2967 flour. All types of composite flour sevs were organoleptically acceptable upto 90 days of storage and fell in the category of' 'liked moderately' to 'liked very much'. The total bacterial count of sev of WH-1129:SGF:SBF $(60: 30: 10)$ and $(40: 40: 20)$ varied from 0 to $7 \times 10^{2}$ and 0 to $8 \times 10^{2} \mathrm{cfu} / \mathrm{g}$ of sev, respectively while that of HD:SGF:SBF (60:30:10) and (40:40:20) ranged from 0 to $9 \times 10^{2}$ and 0 to $8 \times 10^{2} \mathrm{cfu} / \mathrm{g}$ of sev, respectively.

\section{Introduction}

Now a day's savouries and snack foods have become an integral part of the diet and hence offer great scope for development of value added savouries aimed at providing nutrition and health. Soya flour, both full fat and defatted have been used as ingredients in the preparation of high protein snacks. Cereal and legume-based products blended with full fat soya flour were found to have acceptable quality (Gandhi, Mishra, and Ali, 1983). Incorporation of soybean flour into a staple food like wheat and coarse cereal like sorghum is a feasible means of increasing the nutritive value of people's diet. Soya 
proteins have been accepted in many applications because they provide desirable functionalities in fabricated foods at lower cost (Lusas and Rhee, 1995). Defatted soya flour contains about 50-54\% good quality protein and can be used as an ingredient in various types of food (Liu, 1997; Lusas and Riaz, 1995). It has been extensively and widely used for the preparation of various types of value added sev, bakery products like biscuits, cakes, cookies, bread, etc., traditional products like ladoo, chapatti etc., throughout the world (Omueti and Morton, 1996; Marques et al., 2000, Pandey and Sangwan, 2016). Wheat flour is an important source of not only energy and protein but also provides substantial amounts of vitamins and minerals in human diets specially low income group people. Sorghum is important crop for food security in semi-arid and arid regions due to their high nutritional quality and low production inputs. Sorghum is gluten free and can be important food source to millions of people who are intolerant to gluten (celiac disease), including diabetic patients, in both developed and developing countries (Masilamani et al., 2012).

In India, different types of deep fat fried snacks have been studied with particular reference to incorporation of soya flour and sorghum flour in traditional Indian snacks and sweets such as murukku, methu pakkoda, sev and laddu (Jayalakshmi and Neelakantan, 1987; Ahluwalia et al., 1995). In today's world considering the increasing awareness and demand amongst the masses for healthy food alternatives containing high protein, which are also, cost effective have led scientists to develop value added products from locally and easily available ingredients. Keeping this in view the present study was undertaken to develop nutrient rich sevs by incorporating wheat, sorghum and soybean flours and were evaluated for organoleptic acceptability, nutritional characteristics and keeping quality.

Materials and Methods

\section{Procurement and processing of raw material}

Two newly released wheat (Triticum aestivum) varieties (WH-1129, HD-2967), traditional wheat variety (C-306) and Sorghum vulgare (HJ-541) used for product development in the present study were procured in a single lot from the breeders, Department of Genetics and Plant Breeding, CCS Haryana Agriculture University, Hisar. Wheat and sorghum grains were cleaned and ground in an electric grinder and flours thus obtained were sieved through a 60 mesh sieve and packed in airtight plastic containers for product development and further analysis. Soybean flour along with other ingredients required for the development of value added sevs were procured from local market

\section{Development and organoleptic characteristics of value added Sevs}

The preparation method of value added sevs is presented in Table 1. Using two ratios (60:30:10 and 40:40:20) of each wheat variety flour (WF), sorghum flour (SGF) and soybean flour (SBF) four types of sevs were developed. $100 \%$ wheat flour sev prepared from C-306 were kept as control.

The sevs were organoleptically evaluated by a panel of ten judges for sensory parameters like colour, appearance, flavour, texture, taste and overall acceptability using 9 point hedonic scale ( $1=$ dislike extremely, $5=$ neither like nor dislike, 9 to like extremely). Between tasting different samples, participants rinsed their mouth with warm water. On the basis of organoleptic acceptability, from each category the sevs rated higher for organoleptic characteristics were selected for further study. 


\section{Method}

Sieved flours and added salt, ajwain, turmeric, red chilli powder and baking powder.

Added one table spoon oil in flour mixture and mixed water.

Made soft dough using water.

Made thin sevs of the dough using sev machine directly in hot oil.

Fried and broke into small sevs.

\section{Nutritional characteristics of value added Sevs}

Proximate composition (moisture, crude protein, crude fat, crude fibre and ash) of one most acceptable ratio of sevs developed from wheat, sorghum and soybean flour blends were estimated by employing the standard method of analysis (AOAC, 2000).

\section{Keeping quality of value added Sevs}

The sevs were evaluated for sensory parameters using 9 point hedonic scale by a panel of ten judges and total bacterial count at regular intervals of $0,15,30,45,60,75$ and 90 days.

\section{Estimation of total bacterial count}

Plate count agar media was prepared in distilled water and autoclaved at $121.6^{\circ} \mathrm{C}$ (15psi) for $15 \mathrm{~min}$. All the glassware were sterilized in hot air oven at $160^{\circ} \mathrm{C}$ for 2 hour.

One $\mathrm{g}$ of sample was dissolved into $9.0 \mathrm{ml}$ of sterilized distilled water blank and shaken thoroughly. One ml of 10-1 dilution was taken and dissolved into another $9.0 \mathrm{ml}$ sterilized water blank. This was 10-2 dilution. Similarly
$10-3$ dilution was made. $0.1 \mathrm{ml}$ of $10-1,10-2$ and 10-3 dilutions were poured in petri plate containing PCA media. Plates were incubated at $30 \pm 2^{\circ} \mathrm{C}$ for $24-48$ hours. Numbers of colonies were counted and colony forming unit (cfu) was calculated by using formula:-

No. of colonies $\times$ dilution factor $\times 10=\mathrm{cfu} / \mathrm{g}$ of sample

\section{Statistical analysis}

The data were statistically analysed in complete randomized design for analysis of variance, mean, standards deviation and critical difference according to the standard method (Sheoran and Pannu, 1999).

\section{Results and Discussion}

\section{Organoleptic characteristics}

Table 2 had shown that the control sev had mean score of 6.16 for overall acceptability whereas sev made from composite flour containing 60:30:10 and 40:40:20 level of wheat, sorghum and soybean flours, in both types of wheat flours WH-1129 and HD-2967, had significantly $(\mathrm{P} \leq 0.05)$ higher mean score of overall acceptability in comparison to control. The overall acceptability score was in the category of 'liked very much' and ranged from 7.48 to 8.32 in different types of supplemented sevs. Our findings were in agreement with those of other workers (Singh, 2003, Singh and Sehgal 2008).

\section{Nutritional composition of value added Sevs}

The protein and fat contents in control sev were 9.32 and 13.48 per cent, respectively which significantly $(\mathrm{P} \leq 0.05)$ increased in composite flour sev of WH-1129 wheat flour to 11.36 and 16.55 per cent, respectively and similarly in HD-2967 flour sev increased to 11.19 and 17.14 per cent, respectively (Table 
$3)$. The crude fibre and ash contents in control sev were 1.56 and 3.56 per cent, respectively which significantly $(\mathrm{P} \leq 0.05)$ increased in composite flour sevs at 40:40:20 level in WH1129 flour to 4.23 and 3.87 per cent, respectively and in HD-2967 flour to 3.53 and 3.47 per cent, respectively. WH-1129 wheat flour supplemented sev had significantly $(\mathrm{P} \leq 0.05)$ higher contents of crude fibre and ash content as compared to HD-2967 wheat flour supplemented sev.
These results are in agreement with those of earlier workers (Gupta, 2001; Rani et al., 2008; Punia and Gupta, 2009 and Sangwan and Dahiya, 2013), who found that proximate composition of value added products were higher than that of control products developed from 100 per cent wheat flour. The difference in proximate composition of value added products developed from two different wheat varieties was basically due to difference in the proximate composition of wheat varieties.

Table.1 Ingredients and Preparation Method for Development of Sevs

\begin{tabular}{|c|c|c|c|c|c|c|c|c|c|}
\hline $\begin{array}{c}\text { Supplementation } \\
\text { level }(\%)\end{array}$ & $\begin{array}{l}\text { Wheat } \\
\text { flour } \\
(\mathrm{g})\end{array}$ & $\begin{array}{l}\text { Sorghum } \\
\text { flour } \\
\text { (g) }\end{array}$ & $\begin{array}{l}\text { Soybean } \\
\text { flour } \\
(\mathrm{g})\end{array}$ & $\begin{array}{l}\text { Salt } \\
(\mathrm{g})\end{array}$ & $\begin{array}{l}\text { Ajwain } \\
\text { (g) }\end{array}$ & $\begin{array}{c}\text { Red } \\
\text { chilli } \\
\text { powder } \\
\text { (g) }\end{array}$ & $\begin{array}{l}\text { Turmeric } \\
\text { powder } \\
\text { (g) }\end{array}$ & $\begin{array}{c}\text { Garam } \\
\text { masala } \\
(\mathrm{g})\end{array}$ & Oil \\
\hline Control(100\% WF $)$ & 100 & - & - & 4 & 2 & 4 & 2 & 2 & $\begin{array}{l}\text { For } \\
\text { frying }\end{array}$ \\
\hline $\begin{array}{l}\text { WF: SGF: SBF } \\
60: 30: 10 \\
40: 40: 20\end{array}$ & $\begin{array}{l}60 \\
40\end{array}$ & $\begin{array}{l}30 \\
40\end{array}$ & $\begin{array}{l}10 \\
20\end{array}$ & $\begin{array}{l}4 \\
4\end{array}$ & $\begin{array}{l}2 \\
2\end{array}$ & $\begin{array}{l}4 \\
4\end{array}$ & $\begin{array}{l}2 \\
2\end{array}$ & $\begin{array}{l}2 \\
2\end{array}$ & $\begin{array}{c}\text { For } \\
\text { frying } \\
\text { For } \\
\text { frying }\end{array}$ \\
\hline
\end{tabular}

Table.2 Mean Score of Organoleptic Acceptability of Value Added Sevs

\begin{tabular}{|c|c|c|c|c|c|c|}
\hline Products & Colour & Appearance & Aroma & Texture & Taste & $\begin{array}{c}\text { Overall } \\
\text { acceptability }\end{array}$ \\
\hline \multicolumn{7}{|l|}{ Sev } \\
\hline $\begin{array}{c}\text { Control } \\
\text { (100\% WF) }\end{array}$ & $6.20 \pm 0.13$ & $6.30 \pm 0.21$ & $5.90 \pm 023$ & $6.30 \pm 0.21$ & $6.10 \pm 0.23$ & $6.16 \pm 0.08$ \\
\hline Type I & $7.80 \pm 0.25$ & $7.90 \pm 0.23$ & $8.10 \pm 0.24$ & $7.90 \pm 0.18$ & $7.90 \pm 0.18$ & $7.92 \pm 0.05$ \\
\hline Type II & $8.50 \pm 0.17$ & $8.50 \pm 0.17$ & $8.10 \pm 0.23$ & $8.10 \pm 0.23$ & $8.40 \pm 0.22$ & $8.32 \pm 0.09$ \\
\hline Type III & $7.60 \pm 0.16$ & $7.50 \pm 0.21$ & $7.70 \pm 0.15$ & $7.20 \pm 0.13$ & $7.40 \pm 0.16$ & $7.48 \pm 0.08$ \\
\hline Type IV & $7.90 \pm 0.18$ & $7.70 \pm 0.21$ & $7.90 \pm 0.23$ & $7.50 \pm 0.22$ & $8.00 \pm 0.15$ & $7.80 \pm 0.09$ \\
\hline $\mathrm{CD}(\mathrm{P} \leq 0.05)$ & 0.52 & 0.57 & 0.63 & 0.57 & 0.50 & 0.24 \\
\hline
\end{tabular}

Type I (WH-1129: SGF: SBF 60:30:10) Type II (WH-1129: SGF: SBF 40:40:20)

Type III (HD-2967: SGF: SBF 60:30:10) Type IV (HD-2967: SGF: SBF 40:40:20)

$\mathrm{WF}=$ Wheat flour $(\mathrm{WH}-1129$ and HD-2967). SGF= Sorghum flour. SBF=Soybean flour 
Int.J.Curr.Microbiol.App.Sci (2018) 7(1): 3081-3087

Table.3 Proximate Composition of Composite Flour Sevs (\%, on dry matter basis)

\begin{tabular}{|c|c|c|c|c|c|}
\hline $\begin{array}{c}\text { Supplementation } \\
\text { level (\%) }\end{array}$ & Moisture & Protein & Fat & Crude fibre & Ash \\
\hline Sev & & & & & \\
\hline Control (100\% WF) & $12.97 \pm 0.04$ & $9.32 \pm 0.02$ & $13.48 \pm 0.10$ & $1.56 \pm 0.03$ & $3.56 \pm 0.06$ \\
\hline Type II & $13.87 \pm 0.05$ & $11.36 \pm 0.04$ & $16.55 \pm 0.33$ & $4.23 \pm 0.09$ & $3.87 \pm 0.02$ \\
\hline Type IV & $13.39 \pm 0.06$ & $11.19 \pm 0.09$ & $17.14 \pm 0.65$ & $3.53 \pm 0.12$ & $3.47 \pm 0.06$ \\
\hline CD(P<0.05) & 0.19 & 0.21 & 1.50 & 0.31 & 0.18 \\
\hline
\end{tabular}

Type II (WH-1129: SGF: SBF 40:40:20) Type IV (HD-2967: SGF: SBF 40:40:20)

$\mathrm{WF}=$ Wheat flour $(\mathrm{WH}-1129$ and HD-2967). SGF= Sorghum flour. SBF=Soybean flour

Table.4 Effect of Storage Period on Overall Acceptability Scores of Wheat, Sorghum and Soybean Composite Flour Sevs

\begin{tabular}{|c|c|c|c|c|c|c|c|c|}
\hline \multirow{2}{*}{$\begin{array}{l}\text { Supplementation } \\
\text { level }(\%)\end{array}$} & \multicolumn{8}{|c|}{ Storage period (days) } \\
\hline & $\mathbf{0}$ & 15 & 30 & 45 & 60 & 75 & 90 & Mean \\
\hline \multicolumn{9}{|c|}{ Overall Acceptability } \\
\hline $\begin{array}{c}\text { Control (100\% } \\
\text { WF) }\end{array}$ & $6.16 \pm 0.12$ & $5.94 \pm 1.16$ & $5.68 \pm 0.22$ & $5.50 \pm 0,26$ & $5.34 \pm 1.15$ & $5.08 \pm 0.17$ & $4.90 \pm 0.19$ & $5.46 \pm 0.21$ \\
\hline Type I & $7.92 \pm 0.09$ & $7.68 \pm 0.13$ & $7.46 \pm 0.21$ & $7.26 \pm 0.13$ & $7.08 \pm 0.10$ & $6.78 \pm 0.22$ & $6.56 \pm 0.14$ & $7.18 \pm 0.11$ \\
\hline Type II & $8.32 \pm 0.20$ & $8.04 \pm 0.09$ & $7.80 \pm 0.16$ & $7.60 \pm 0.15$ & $7.42 \pm 0.12$ & $7.02 \pm 0.15$ & $6.74 \pm 0.09$ & $7.54 \pm 0.21$ \\
\hline Type III & $7.48 \pm 0.10$ & $7.30 \pm 0.16$ & $7.14 \pm 0.18$ & $6.96 \pm 0.20$ & $6.82 \pm 1.15$ & $6.68 \pm 0.13$ & $6.54 \pm 0.25$ & $6.94 \pm 0.10$ \\
\hline Type IV & $7.80 \pm 0.12$ & $7.58 \pm 0.14$ & $7.42 \pm 0.19$ & $7.32 \pm 0.15$ & $7.12 \pm 0.22$ & $7.00 \pm 0.11$ & $6.72 \pm 0.20$ & $7.24 \pm 0.17$ \\
\hline Mean & 7.53 & 7.30 & 7.10 & 6.92 & 6.75 & 6.51 & 6.29 & \\
\hline $\mathrm{CD}(\mathrm{P} \leq 0.05)$ & $\begin{array}{l}\text { Period: } \\
0.19\end{array}$ & $\begin{array}{l}\text { Supplementation } \\
\text { level: } 0.16\end{array}$ & $\begin{array}{c}\text { Period } x \\
\text { Supplementation } \\
\text { level: NS }\end{array}$ & & & & & \\
\hline
\end{tabular}

Type I (WH-1129: SGF: SBF 60:30:10) Type II (WH-1129: SGF: SBF 40:40:20)

Type III (HD-2967: SGF: SBF 60:30:10) Type IV (HD-2967: SGF: SBF 40:40:20)

$\mathrm{WF}=$ Wheat flour $(\mathrm{WH}-1129$ and HD-2967). SGF $=$ Sorghum flour. SBF $=$ Soybean flour

Table.5 Total Bacterial Count (Cfu/G) of Composite Flour Sevs at Different Storage Period (On Dry Weight Basis)

\begin{tabular}{|c|c|c|c|c|c|c|c|}
\hline \multirow{3}{*}{$\begin{array}{l}\text { Supplementation level } \\
(\%)\end{array}$} & \multicolumn{7}{|c|}{ Storage period (days) } \\
\hline & \multicolumn{7}{|c|}{ Total bacterial count (cfu/g) } \\
\hline & $\mathbf{0}$ & 15 & 30 & 45 & 60 & 75 & 90 \\
\hline Control (100\% WF) & 0 & $1 \times 10^{1}$ & $4 \times 10^{2}$ & $9 \times 10^{2}$ & $24 \times 10^{2}$ & $39 \times 10^{2}$ & $48 \times 10^{2}$ \\
\hline Type II & 0 & $2 \times 10^{1}$ & $4 \times 10^{2}$ & $8 \times 10^{2}$ & $34 \times 10^{2}$ & $42 \times 10^{2}$ & $51 \times 10^{2}$ \\
\hline Type IV & 0 & $2 \times 10^{1}$ & $5 \times 10^{2}$ & $8 \times 10^{2}$ & $29 \times 10^{2}$ & $41 \times 10^{2}$ & $53 \times 10^{2}$ \\
\hline
\end{tabular}

Type II (WH-1129: SGF: SBF 40:40:20) Type IV (HD-2967: SGF: SBF 40:40:20)

WF=Wheat flour (WH-1129 and HD-2967). SGF= Sorghum flour. SBF=Soybean flour cfu=colony forming unit 


\section{Keeping quality of value added Sevs}

Table 4 had shown that mean scores of overall acceptability in control, WH1129:SGF:SBF (60:30:10 and 40:40:20), and HD:SGF:SBF (60:30:10 and 40:40:20) sev showed gradual decrease from 6.16 (zero day) to 4.90 (90 ${ }^{\text {th }}$ day), 7.92 (zero day) to 6.56 $\left(90^{\text {th }}\right.$ day) and 8.32 (zero day) to $6.74\left(90^{\text {th }}\right.$ day) and 7.48 (zero day) to 6.54 ( $90^{\text {th }}$ day) and 7.800 (zero day) to $6.72\left(90^{\text {th }}\right.$ day), respectively during storage. On mean basis the sevs fell in the category of 'neither liked nor disliked' (control), 'liked moderately' (WH-1129: SGF: SBF (60:30:10) and both levels of supplementation of HD-2967 value added sev) and 'liked very much' (WH-1129: SGF: SBF, 40: 40: 20). The total bacterial count of control sev varied from 0 to $9 \times 10^{2}$ $\mathrm{cfu} / \mathrm{g}$ of sev during zero to $45^{\text {th }}$ day of storage (Table 5). The total bacterial count of WH1129:SGF:SBF (60:30:10) and (40:40:20) varied from 0 to $7 \times 10^{2}$ and 0 to $8 \times 10^{2} \mathrm{cfu} / \mathrm{g}$ of sev, respectively while that of HD:SGF:SBF (60:30:10) and (40:40:20) ranged from 0 to $9 \times 10^{2}$ and 0 to $8 \times 10^{2} \mathrm{cfu} / \mathrm{g}$ of $\mathrm{sev}$, respectively. These findings are in agreement with those of several other workers (Sangwan and Dahiya, 2013; Chandel, 2014; Rana, 2015) who found that the value added products developed from composite flour could be stored upto 90 days.

The utilisation of alternative sources of food specially less utilised coarse cereals and refinement of technology is need of the hour. From the present study it is concluded that protein rich soybean and coarse cereals like sorghum can be utilised for supplementing the wheat flour which is staple diet of the population. The development and utilization of the composite flour sevs on one hand will promote value addition of the products and on the other hand will provide low cost nutritious alternatives specially in poor developing countries for combating malnutrition among children and vulnerable sections of the society. Setting up of small scale industries for production of sevs by rural women will ensure the economic, food and nutrition security and it will also encourage utilisation of low input, sustainable crops, together with staple crops.

\section{Acknowledgement}

I am extremely grateful to my advisor Dr. Veenu Sangwan and Department of Foods and Nutrition, CCS HAU, Hisar, Haryana for providing all facilities related to my research work.

\section{References}

Ahluwalia, T., Usha, M. S., and Awasthi, P. 1995. Traditional snack foods from defatted soy flour: textural properties and consumer acceptance. Beverage and Food World, May, 22-24.

AOAC, 2000. Official Methods of Analysis of Association of Official Analytical Chemists. Washington, D.C.

Chandel, J., 2014. Development, Acceptability and Nutritional Evaluation of Linseed Supplemented Value-Added Products. M.Sc. Thesis, CCS Haryana Agricultural University, Hisar, India.

Gandhi, A. P., Mishra, V. K., and Ali, N. 1983. Organoleptic assessment of full fat soy flour in various indigenous products. J. Food Technol, 18, 771-775.

Gupta, S., 2001. Utilization of Vegetable Powder for Value Added Baked Product. M.Sc. Thesis, CCS Haryana Agricultural University, Hisar, India.

Jayalakshmi, N., and Neelakantan, S. 1987. Studies on the acceptability of sorghum-soya blends in south Indian dishes and their keeping quality. Indian J Nutr Diet, 24, 136-141 
Liu, K. 1997. Soybeans: chemistry, technology and utilization. Gaithersburg, Maryland: Aspen Publishers.

Lusas, E. W., and Riaz, M. N. 1995. Soy protein products: processing and use. $\mathrm{J}$ Nutr, 125, 573S-580S.

Lusas, E. W., Rhee, K. C. 1995. Soy protein processing and utilization. In D. R. Erickson (Ed.), Practical handbook of soybean processing and utilization (pp. 129-133, 151-157). Champaign, Ilinois and St. Louis, Missouri: AOCS Press and United Soybean Board.

Marques, M. D. F., Bora, P. S., and Narain, N. 2000. Development of some high protein conventional foods based on wheat and oilseed flours. J. Food Sci. Technol, 37(4), 394-399.

Masilamani, M., Wei, J., and Sampson, H.A, 2012. Regulation of the Immune Response by Soybean Isoflavones. Immunological Research. 54; 95-110.

Omueti, O., and Morton, I. D. 1996. Development by extrusion of soyabari snack sticks: a nutritionally improved soya-maize product based on the nigerian snack (kokoro). Int. J. Food Sci. Nutr, 47, 5-13.

Pandey, L. And Sangwan V. 2016. Keeping Quality of Sorghum Soybean Supplemented Wheat Flour Ladoos. Int. J. Adv. Nutr. Health sci, 2016. 4(1); 196-202.

Punia, D. and Gupta, M, 2009. Sensory Characteristics, Nutrient Composition and Storage Studies of Value Added Products for Children. J Nutr Food Sci, 39 (5) 503-510.

Rana, N., 2015. Nutritional Evaluation and Acceptability of Value Added Products Based on Composite Flour (Pearl Millet-Sorghum-Mungbean-Marwa).

Ph.D. Thesis, CCS Haryana Agricultural University, Hisar, India.

Rani, V., Grewal, R.B., and Khetarpaul, N., 2008. Sensory and Nutritional Evaluation of Soy Supplemented Nutritious Baked Products. J Dairy Foods Home Sci, 27 (3/4) 209-215.

Sangwan, V. and Dahiya, S., 2013. PhysicoChemical and Nutritional Properties of Wheat-Sorghum-Soybean Composite Flours and Their Biscuits. Asian J. Dairy Fd. Res. 32 (1) 65-70.

Sheoran, O.P, Tonk, D.S., Hasija, R.C., and Pannu, R.S., 1998. Statistical Software Package for Agricultural Research Workers in Recent Advances in Information Theory, Statistics and Computer Application. Hooda D.S. and Hasija R.C. (eds.) 139-143.

Singh, G. and Sehgal, S. 2008. Nutritional Evaluation of Ladoo Prepared from Popped Pearl Millet. J Nutr Food Sci. 38 ; 310-315.

Singh, G., 2003. Development and Nutritional Evaluation of Value Added Products from Pearl Millet (Pennisetum glaucum). Ph.D. Thesis, CCS Haryana Agricultural University, Hisar, India.

\section{How to cite this article:}

Laxmi Pandey, Veenu Sangwan and Kamla Malik. 2018. Nutritional and Keeping Quality Characteristics of Value Added Composite Flour Sev. Int.J.Curr.Microbiol.App.Sci. 7(01): 3081-3087. doi: https://doi.org/10.20546/ijcmas.2018.701.365 